\title{
ZAŠTITA OSOBNIH PODATAKA I EUROPSKA KONVENCIJA ZA ZAŠTITU LJUDSKIH PRAVA I TEMELJNIH SLOBODA ${ }^{1}$
}

\author{
UDK: $35: 342(4)$ \\ Pregledni rad \\ Primljeno: 1. 6. 2016.
}

\begin{abstract}
Predmet ovoga rada jest zaštita osobnih podataka kao temeljnog ljudskog prava u svjetlu Europske konvencije za zaštitu ljudskih prava i temeljnih sloboda. Daju se prikaz i analiza odredbi Konvencije za zaštitu pojedinaca pri automatskoj obradi osobnih podataka Vijeća Europe, kao temeljnog pravnog akta koji uređuje zaštitu osobnih podataka i pravo na privatnost pojedinca, a koji u odnosu na Europsku konvenciju za zaštitu ljudskih prava i temeljnih sloboda predstavlja lex specialis, koji se posebno bavi jednom kategorijom ljudskih prava, koja, zbog ubrzanog tehnološkog razvoja, postaje sve značajnija i važnija. Nakon analize načela koje sadrži Konvencija za zaštitu pojedinaca pri automatskoj obradi osobnih podataka, i koja kao takva predstavljaju osnovu za uspostavu pravnog okvira Europske unije za zaštitu osobnih podataka, analizira se Direktiva Europskog parlamenta i Europskog vijeća o zaštiti pojedinaca u vezi s obradom osobnih podataka i slobodnom protoku takvih podataka, kao i odgovarajući propisi u državama članicama: Hrvatskoj, Velikoj Britaniji, Francuskoj, Njemačkoj i Nizozemskoj. Na kraju se iznose empirijski pokazatelji vezani uz korištenje osobnih podataka, te se u zaključku interpretiraju rezultati istraživanja kroz analizu važnosti koju ima zaštita osobnih podataka kao poseban oblik zaštite ljudskih prava u svjetlu Europske konvencije za zaštitu ljudskih prava i temeljnih sloboda.
\end{abstract}

\section{Ključne riječi: javna uprava, ljudska prava i temeljne slobode, zaštita osobnih podataka}

\section{UVOD}

Predmet ovoga rada jest zaštita osobnih podataka u svjetlu Europske konvencije za zaštitu ljudskih prava i temeljnih sloboda. Pravo na zaštitu osobnih podataka, kao i pravo na privatnost jedno je od najvažnijih ljudskih prava. Ono je, kao temeljno ljudsko pravo, uređeno propisima različitih država. Zbog razvoja suvremenih informacijskih i komunikacijskih tehnologija, ovo će pravo dobivati

1 Rad je nastao u okviru projekta „Primjena Europske konvencije za zaštitu ljudskih prava u hrvatskom i slovenskom pravnom sustavu“", koji u suradnji izvode Pravni fakultet u Zagrebu i Fakultet za državne in evropske študije iz Kranja. Rad je prezentiran 19. svibnja 2015. godine na Pravnom fakultetu u Zagrebu na međunarodnoj znanstvenoj konferenciji pod nazivom „Primjena Europske konvencije za zaštitu ljudskih prava u hrvatskom i slovenskom pravnom sustavu“. 
sve više na značaju jer se nerijetko može svjedočiti njegovu izravnom kršenju, kao i zlouporabi suvremenih medija, poput interneta, koji omogućuje da se praktički svaki podatak može objaviti i nakon toga nekontrolirano širiti. Upravo je zbog toga zaštita osobnih podataka globalan problem jer nacionalna zakonodavstva najčešce uređuju zaštitu osobnih podataka u okviru nacionalnih jurisdikcija, dok internet, kao globalna virtualna mreža, ne poznaje nacionalne granice ni barijere. Utoliko je više interesantna situacija na području EU, koja u prvom redu predstavlja zajedničku carinsku uniju, ali i zajedničko tržište kapitala, proizvoda, usluga i rada. Ovdje pitanje uporabe osobnih podataka nije nešto što bi bilo samo od interesa za države članice, nego kao takvo, zbog prirode osobnih podataka, koji svjedoče o navikama i sklonostima pojedinaca, daje sliku i o potrošačkim sklonostima, što je nesumnjivo interesantno subjektima koji djeluju na zajedničkom europskom tržištu. Upravo zbog toga, zaštita osobnih podataka ne može samo biti pitanje koje je regulirano propisima nacionalnih zakonodavstava, nego se radi i o temi koja je značajna u širem, europskom kontekstu. Pored navedenog užeg interesa, koji je vezan uz činjenicu da je Europska unija u prvom redu carinska unija, kao i zajedničko tržište različitih proizvoda i usluga, ali isto tako i prostor koji teži i monetarnoj i sigurnosnoj integraciji, nesumnjivo je da pitanje zaštite osobnih podataka ima i dodatnu dimenziju. Posebice se to odnosi na tijela javne vlasti koja raspolažu brojnim osobnim podacima pojedinaca, gdje je potrebno jasno precizirati pravila kada i pod kojim se uvjetima ti podaci mogu međusobno razmjenjivati. U tom smislu, Europska je unija 1995. godine donijela novu regulaciju kojom je uređena zaštita osobnih podataka. Europska je komisija, zbog posebne važnosti koju pridaje ovom području, 2012. godine uputila u Europski parlament i prijedlog nove Direktive, kojom se na sustavan i cjelovit način želi urediti ovo područje. Njezino donošenje stavljeno je na listu prioriteta rada Komisije za 2015. godinu. Temeljem ove regulacije, Komisija provodi politiku zaštite osobnih podataka, a Eurobarometar je napravio i posebno istraživanje kojim je nastojao utvrditi povjerenje građana glede zaštite njihovih osobnih podataka.

Predmet ovoga rada bit će analiza zaštite osobnih podataka, onako kako je to predviđeno Zakonom o zaštiti osobnih podataka, odgovarajućim ustavnim odredbama kojima se postavljaju temelji za njihovu zaštitu, ali i teorijskim okvirom kojim se želi postaviti osnova za razvoj dobre prakse na ovom području. Posebno se u tom smislu često koristi pojam informacijske privatnosti (Information Privacy), koji podrazumijeva različite aspekte vezane uz reguliranje korištenja osobnih podataka, koji u uvjetima strelovitog razvoja informacijskih i komunikacijskih tehnologija postaju dostupniji nego ikad, s potencijalnim, često puta neugodnim, posljedicama što mogu nastati za osobe na koje se odnose. 
Drugi dio rada bit će posvećen pitanju regulacije zaštite osobnih podataka na području Europske unije, s emirijskim podacima vezanima uz provedbu ovog regulacijskog okvira, kojim se nastoji osigurati zaštita privatnosti pojedinca i njegovog osobnog i obiteljskog života. Detaljna analiza ove regulacije nužna je zato što predstavlja zajednički pravnu stečevinu, koju su tijela javne vlasti država članica dužna po potrebi i izravno primjenjivati. Na kraju će se analizirati Europska konvencija za zaštitu ljudskih prava i temeljnih sloboda u dijelu koji se odnosi na zaštitu osobnih podataka s određenim mehanizmima za njihovu zaštitu. Time će se na cjelovit i sustavan način dati pregled postojećeg stanja, kao i moguće naznake razvoja ovog oblika zaštite u okviru Europskog upravnog prostora. Ovim se radom pokušava objasniti važnost temeljitog uređenja ovog prostora, posebice zbog okolnosti što suvremene komunikacijske i informacijske tehnologije otvaraju prostor brojnim zlouporabama na ovom području, čime se u značajnoj mjeri upravo ugrožavaju ljudska prava, čija je zaštita regulirana i Europskom konvencijom za zaštitu ljudskih prava i temeljnih sloboda.

\section{EUROPSKA KONVENCIJA ZA ZAŠTITU LJUDSKIH PRAVA I TEMELJNIH SLOBODA I PRAVO NA ZAŠTITU OSOBNIH PODATAKA}

Pravo na zaštitu osobnih podataka predstavlja jedno od temeljnih ljudskih prava. To je pravo uređeno čitavim nizom različitih propisa u različitim zemljama, a na području Europske unije uređeno je regulatornim okvirom, koji generalno vrijedi za sve članice Unije. Ovaj regulatorni okvir u prvom redu se temelji na Direktivi Europskog parlamenta i Europskog vijeća o zaštiti pojedinaca u vezi s obradom osobnih podataka i slobodnom protoku takvih podataka. ${ }^{2}$ Kao drugi važan dokument smatra se i Europska konvencija za zaštitu ljudskih prava i temeljnih sloboda, ${ }^{3}$ koja obuhvaća puno širi sadržaj nego direktiva Europske unije. I ona se smatra važnim pravnim okvirom kako za zaštitu prava pojedinaca općenito, tako i za zaštitu ljudskih prava na području zaštite osobnih podataka. Europska konvencija za zaštitu ljudskih prava i temeljnih sloboda ima generalno značenje u smislu općenito postavljene zaštite temeljnih ljudskih prava i sloboda. Tako se u članku 7.1. Konvencije navodi kako svatko ima pravo na poštovanje svog privatnog i obiteljskog života, doma i dopisivanja. Javna se vlast neće miješati u ostvarivanje toga prava, osim u skladu sa zakonom i ako je u demokratskom društvu nužno radi

2 Directive on the European Parliament an the Council of 24 October 1995 on the protection of individuals with regard to the processing of personal data and on the free movement of such a data, 95/46/ EC.

Narodne novine, Međunarodni ugovori br. 18/1997, 14/2002, 13/2003, 09/2005, 01/2006, 02/2010. 
interesa državne sigurnosti, javnog reda i mira, ili gospodarske dobrobiti zemlje, te radi sprečavanja nereda i zločina, radi zaštite zdravlja ili morala ili zaštite prava i sloboda drugih.

Analizom iznesenih odredbi vidljivo je kako se nigdje izrijekom ne spominje zaštita osobnih podataka. Međutim prva odredba članka jasno govori kako se javne vlasti obvezuju na poštovanje osobnog života te dopisivanja. To, među ostalim, nesumnjivo uključuje zaštitu osobnih podataka, ukoliko se kao osobni podatak smatra svaki oni podatak koji nedvojbeno identificira pojedinca ili je povezan s određenim pojedincem. Moglo bi se tako posredno zaključiti kako Europska konvencija za zaštitu ljudskih prava i temeljnih sloboda načelno štiti sva temeljna ljudska prava koja uključuju pravo na privatnost pojedinca, a zaštita osobnih podataka nedvojbeno bi bila sastavni dio prava na privatnost u najširem smislu. Odredbe same Konvencije ne razrađuju detaljno pitanje zaštite privatnosti pojedinca, nego se koriste opći termini kao „poštovanje privatnog i obiteljskog života“, ,poštovanje (nepovredivosti) ${ }^{4}$ doma“ i „poštovanje prava na dopisivanje“. Pa ipak, navedeni termini nesumnjivo predstavljaju kvalitetnu polazišnu osnovu temeljem koje se može razviti odgovarajući regulatorni okvir za zaštitu osobnih podataka. U tom smislu, Europska je unija donijela više različitih propisa kojima je nastojala urediti zaštutu osobnih podataka, uzimajući kao polazišnu osnovu, među drugim pravnim dokumentima, i Europsku konvenciju za zaštitu ljudskih prava i temeljnih sloboda. ${ }^{5}$

Razvoj suvremenih informacijskih i komunikacijskih tehnologija dovodi do pojave čitavog niza problema vezanih uz osiguranje zaštite osobnih podataka. Razvoj interneta, različitih informacijskih kanala poput You Tubea, pojava virtualnih društvenih mreža poput Facebooka i Twittera, nagli razvoj on-line trgovine kao i razvoj sve novijih tehnologija koje duboko zadiru u privatnost pojedinaca, dovodi do posve nove razine potreba u razvoju regulatornog okvira koji uređuje korištenje osobnih podataka. Privatnost tako može biti narušena od drugih subjekata neovlaštenim objavama, korištenjem osobnih podataka od strane privatnih tvrtki, te od same države koja ima čitav niz podataka o građanima što ih obrađuju različita državna tijela.

Gledajući interese države, suvremene komunikacijske tehnologije trebale bi pridonijeti podizanju opće razine sigurnosti, te smanjenju devijantnih oblika ponašanja, poput porezne evazije, različitih oblika financijskih i drugih prijevara,

4 Op. autora.

5 Drugi važni dokumenti koji su posložili kao pravna podloga za zaštitu osobnih podataka jesu Povelja o temeljnim pravima Europske unije, te Konvencija 108 Vijeća Europe o zaštiti pojedinaca vezanoj uz automatsku obradu osobnih podataka. Izvor: http://ec.europa.eu/justice/data-protection/law/ index_en.htm. Preuzeto 20. svibnja 2015. 
učinkovitijoj borbi s organiziranim kriminalom, korupcijom i sl. Stoga se uvijek postavlja pitanje kako pomiriti potrebu za zaštitom privatnosti pojedinca $\mathrm{s}$ legitimnim nastojanjima države da razvije efikasne instrumente za borbu protiv kriminala i korupcije, jer je teško ponekad povući granicu vezanu uz opravdanost korištenja tih sredstava.

Što se pak tiče narušavanja prava na privatnost od strane drugih pojedinaca ili privatnih tvrtki, nesumnjivo je da je posljednjih nekoliko godina, zbog izuzetno brzog razvoja informacijskih i komunikacijskih tehnologija, stvoren ogroman prostor za manipuliranje i zlouporabu osobnih podataka. Očito je da je sadašnje stanje takvo da zahtijeva prilagodbu postojećih pravnih okvira u pravu Europske unije.

\section{KONVENCIJA ZA ZAŠTITU POJEDINACA PRI AUTOMATSKOJ OBRADI OSOBNIH PODATAKA VIJEĆA EUROPE}

Konvencija za zaštitu pojedinaca pri automatskoj obradi osobnih podataka Vijeća Europe iz 1981. godine utvrđuje osnovna načela za zaštitu osobnih podataka građana. ${ }^{6}$ Tako se u poglavlju II. navodi kako će osobni podaci koji prolaze automatsku obradu podataka biti: pribavljeni i obrađeni pošteno i u skladu sa zakonom, pohranjeni za određene i zakonite svrhe i neće biti korišteni na način neprimjeren tim svrhama; primjereni relevantni i ne prekomjerni u odnosu na svrhe zbog kojih se pohranjuju; točni i ondje gdje je potrebno ažurirani prema najnovijim podacima; sačuvani u obliku koji dopušta identifikaciju predmeta ne dulje nego što je potrebno za svrhe za koje se ti podaci pohranjuju (čl. 5. Konvencije). Osobni podaci koji otkrivaju rasno podrijetlo, politička mišljenja ili vjerska ili druga uvjerenja, kao i osobni podaci koji se odnose na zdravlje ili spolni život, ne mogu se automatski obrađivati, osim ako domaći zakon ne osigura odgovarajuću zaštitu. Isto će se primijeniti na osobne podatke koji se odnose na kaznene presude (čl. 6. Konvencije). Poduzet će se prikladne mjere sigurnosti za zaštitu osobnih podataka pohranjenih u automatskim datotekama podataka od slučajnog ili bespravnog uništavanja ili slučajnog gubitka, kao i od neovlaštenog pristupa, izmjene ili diseminacije (čl. 7. Konvencije). Prema odredbama Konvencije, svakoj će osobi biti omogućeno da

6 Tekst Konvencije za zaštitu pojedinaca pri automatskoj obradi osobnih podataka preuzet je iz: Zaštita osobnih podataka i dostupnost informacija: preporuke Vijeća Europe, Hrvatski državni arhiv, Zagreb, 2002., str. 11-12. Navedena je Konvencija sastavni dio pravnog poretka Republike Hrvatske, a implementirana je donošenjem Zakona o potvrđivanju Konvencije za zaštitu osoba glede automatizirane obrade osobnih podataka u vezi s nadzornim tijelima i međunarodnom razmjenom podataka i Dodatnog protokola uz Konvenciju za zaštitu osoba glede automatizirane obrade osobnih podataka u vezi s nadzornim tijelima i međunarodnoj razmjeni podataka, Narodne novine br. 04/2005, Međunarodni ugovori. 
ustanovi postojanje automatske datoteke osobnih podataka, njezine glavne svrhe, kao i identitet i stalno boravište ili glavno mjesto poslovanja nadzornika datoteke; da u razumnim razmacima i bez pretjeranog odgađanja ili troška dobije potvrdu o tome jesu li osobni podaci koji se tiču nje pohranjeni u automatskoj datoteci podataka, kao i da joj se takvi podaci proslijede u razumljivu obliku; da se takvi podaci, prema potrebi, isprave ili izbrišu, ako su bili obrađivani suprotno odredbama domaćeg prava; da joj je dostupan pravni lijek, ako nije udovoljeno zahtjevu za potvrdom ili, ako nastupi taj slučaj, prosljeđivanjem, ispravkom ili brisanjem... (čl. 8. Konvencije). Opoziv odredbi iz čl. 5, 6 i 8 Konvencije bit će dopušten kad je takav opoziv predviđen zakonodavstvom strane i ako u demokratskom društvu to čini nužnu mjeru u interesu zaštite nacionalne sigurnosti, javne sigurnosti, monetarnih interesa države ili suzbijanja kaznenih djela, te kod zaštite predmeta podataka ili prava i sloboda drugih (čl. 9. st. 2. Konvencije).

Temeljem analize ovih odredbi, vidi se kako su visoko postavljeni standardi glede zaštite osobnih podataka pojedinaca, a posebice oni podaci koji se odnose na osjetljive kategorije podataka, kao što su rasno podrijetlo, politička mišljenja ili vjerska ili druga uvjerenja, kao i osobni podaci koji se odnose na zdravlje ili spolni život. U tom smislu, ova Konvencija predstavlja svojevrsni lex specialis u odnosu na Europsku konvenciju za zaštitu ljudskih prava i temeljnih sloboda, jer razrađuje jedno od temeljnih prava pojedinaca, pravo na zaštitu privatnosti. Ukoliko se pođe od toga da razvoj komunikacijskih i informacijskih tehnologija snažno utječe na pitanja koja su vezana uz zaštitu osobnih podataka i zaštitu privatnosti pojedinaca, i to posebice na internetu i društvenim mrežama, očito je da Konvencija ima vrlo važnu pravnu podlogu kojom se osigurava ova kategorija ljudskih prava, koja je, upravo zbog tehnološkog razvoja, posebno ugrožena. Ovom se Konvencijom određuju minimalni standardi vezani uz zaštitu osobnih podataka i postupanje s njima, te kao takva predstavlja podlogu koja je posložila kao polazna osnova za kreiranje pravnog okvira za zaštitu osobnih podataka na području Europske unije.

\section{PRAVNI OKVIR ZA ZAŠTITU OSOBNIH PODATAKA NA PODRUČJU EUROPSKE UNIJE}

Temeljni propis koji regulira zaštitu osobnih podataka u Europskoj uniji jest Direktiva Europskog parlamenta i Europskog vijeća o zaštiti pojedinaca u vezi s obradom osobnih podataka i slobodnim protokom takvih podataka iz 1995. godine. Kako je navedena Direktiva stara 20 godina, i kako uređuje područje koje ima izuzetno dinamičan društveni razvoj, Europska komisija je već 2012. godine izradila i predala na raspravu prijedlog Regulacije o zaštiti pojedinaca glede obrade 
osobnih podataka i slobodnog kretanja takvih podataka. ${ }^{7}$ Očekuje se da bi moglo doći do donošenja novih propisa na području Europske unije do kraja 2015. godine.

U preambuli Direktive navode se razlozi koji su doveli do njezina donošenja. Među važnije razloge ovdje se može iznijeti kako uspostava i funkcioniranje unutarnjeg tržišta, u kojem je osigurano slobodno kretanje dobara, usluga, osoba i kapitala, podrazumijeva i slobodno kretanje osobnih podataka iz jedne države članice u drugu, ali isto tako i očuvanje prava pojedinaca. U zajednici dolazi do sve veće obrade osobnih podataka u gospodarske svrhe, zahvaljujući razvoju elektroničkih tehnologija, što znatno olakšava obradu i razmjenu takvih podataka. Gospodarska i socijalna integracija do koje dolazi zbog uspostave i funkcioniranja unutarnjeg tržišta dovest će do znatnog povećanja prekograničnog prijenosa osobnih podataka između svih onih koji su uključeni u gospodarske i socijalne aktivnosti u državama članicama, a razmjena osobnih podataka bit će i dodatno povećana zbog zahtjeva državnih tijela u državama članicama kako bi mogli ispunjavati svoje zakonske funkcije. Razlike u zakonskim propisima među državama članicama koje uređuju zaštitu osobnih podataka mogu dovesti do toga da neke države članice budu spriječene dostavljati takve podatke drugim državama članicama, a to može predstavljati zapreku za provedbu niza gospodarskih aktivnosti na području Unije, narušiti tržišno natjecanje i spriječiti tijela u obavljanju njihovnih aktivnosti na razini Zajednice i u skladu s njezinim pravnim okvirom. Stoga je nužno izgraditi odgovarajući pravni okvir koji će osigurati nužno usklađivanje nacionalnih zakonodavstava na području zaštite osobnih podataka, vodeći pri tome računa da se sačuva visoka razina zaštite osobnih podatataka, a posebice pravo na privatnost. Kako osobi podaci po svojoj prirodi mogu prekršiti temeljne slobode ili privatnost pojedinaca, predviđeno je kako se ne bi smjeli obrađivati bez izričite suglasnosti pojedinaca na koje se odnose, osim kada se podaci iznimno koriste za posebne potrebe. Nadalje, predviđa se mogućnost da države članice budu ovlaštene, kada za to postoji opravdani javni interes, za odstupanje od zabrane obrađivanja osjetljivih kategorija osobnih podataka, i to posebice u područjima kao što su javno zdravstvo i socijalna zaštita, kako bi se osigurali kvaliteta i isplativost postupaka koji se koriste za rješavanje zahtjeva za ostvarivanje pogodnosti i usluga iz sustava zdravstvenog osiguranja.

Prema izričitoj odredbi Direktive, države članice štite temeljna prava i slobode fizičkih osoba, a posebice pravo na privatnost u svezi s obradom osobnih podataka. Države članice ne ograničavaju niti ne zabranjuju slobodni prijenos osobnih podataka među državama članicama. Osobni podatak se definira kao onaj podatak koji se odnosi na utvrđenu ili utvrdivu fizički osobu (odnosno osobu

7 COM (2012.), 11 final, Brussels 25. siječnja 2012. 
čiji se identitet može utvditi izravno i neizravno). Identitet se pak može utvrditi navođenjem identifikacijskog broja ili jednog ili više činitelja značajnih za njezin fizički, fiziološki, mentalni, gospodarski, kulturni ili socijalni identitet. Direktiva se primjenjuje na one osobne podatke koji su predmet automatske obrade, ali i na one podatke čija obrada nije automatska, ali koja je dio sustava arhiviranja, ili će biti predmet sustava arhiviranja.

Države članice trebaju osigurati da se osobni podaci obrađuju zakonito i pošteno, te da su prikupljeni u posebne, izričite i zakonite svrhe, te da ih se dalje ne obrađuje na način koji bi bio nespojiv s tom svrhom. Daljnja obrada podataka u povijesne, statističke ili znanstvene svrhe, sukladno odredbama Direktive, na smatra se nespojivom pod uvjetom da država članica, čiji se osobni podaci analiziraju, osigura odgovarajuću zaštitu. Osobni podaci moraju biti prikupljeni na način da budu relevantni, prikladni i da nisu pretjerani u odnosu na svrhu zbog koje se prikupljaju i dalje obrađuju. U slučaju da osobni podaci nisu točni i potpuni, potrebno je poduzeti odgovarajuće mjere kako bi se ispravili i dopunili. Podaci se moraju čuvati u obliku koji omogućava identifikaciju osoba čiji se podaci obrađuju samo tijekom razdoblja potrebnog u svrhe zbog kojih se podaci prikupljaju ili zbog kojih se dalje obrađuju. Države članice dužne su osigurati odgovarajuću zaštitu za one podatke koji se pohranjuju za dulja razdoblja, ili za povijesnu, statističku i znanstvenu uporabu. Države članice moraju osigurati da se osobni podaci mogu obrađivati samo pod sljedećim uvjetima: osoba čiji se podaci nedvosmisleno obrađuju daje suglasnost za njihovu obradu, obrada je potrebna za izvršavanje ugovora čija je osoba koja se obrađuje stranka, obrada je potrebna radi sukladnosti sa zakonskom obvezom kojoj podliježe nadzornik obrade, obrada je potrebna kako bi se zaštitili vitalni interesi osobe čiji se podaci obrađuju, obrada je potrebna radi izvršavanja zadatka koji se provodi zbog javnog interesa ili pri izvršavanju javnih ovlasti koje ima nadzornik ili treća osoba kojoj se podaci otkrivaju, odnosno kad postoji zakoniti interes nadzornika ili treće strane kojoj se podaci otkrivaju. Države članice načelno ne smiju obrađivati osobne podatke kojima se otkriva rasno ili etničko porijeklo, politička mišljenja, vjera ili filozofska uvjerenja, članstvo u sindikatu i obradu podataka u svezi sa zdravljem ili spolnim životom. ${ }^{8}$

\footnotetext{
Kao iznimke navode se osobni podaci osoba koje su dale svoju izričitu suglasnost za obradu, osim kada je zakonodavstvom države članice predviđeno da se zabrana ne može ukinuti ni u slučaju izričite suglasnosti ispitanika, zatim okolnosti kada se podaci prikupljaju u svezi potreba izvršavanja obveza na području zapošljavanja, gdje se podaci prikupljaju u onoj mjeri koliko je to dopušteno nacionalnim zakonodavstvom, kada je obrada podataka potrebna radi zaštite vitalnih interesa osobe čiji se podaci obrađuju, ili druge osobe, kada osoba čiji se podaci obrađuju nije fizički ili pravno sposobna dati svoju suglasnost, kada se obrada podataka provodi u svrhu zaštite ustanova, udruga ili drugog neprofitnog tijela s političkim, filozofskim, vjerskim ili sindikalnim ciljem i pod uvjetom da se obrada odnosi jedino na članove tijela ili osobe koje su u redovitom kontaktu s njime u pogledu njihove svrhe te da se podaci ne otkrivaju trećoj strani bez suglasnosti osobe čiji se podaci obrađuju, te kad se obrađuju podaci koje je sama osoba objavila. Države članice mogu također obrađivati osobne podatke u svrhu preventivne medicine,
} 
Države članice moraju osigurati da svaka osoba čiji se podaci prikupljaju i obrađuju ima pravo dobiti od nadzornika potvrdu obrađuju li se ili ne obrađuju podaci koji se na nju odnose, podatak vezan uz svrhu obrade, vrste podataka, te primatelje ili barem vrste primatelja, obavijest u razumljivom obliku o podacima koji se obrađuju, te podatke o njihovu izvoru. Osoba čiji se podaci obrađuju ima pravo na prigovor, a države članice moraju osigurati da se besplatno može prigovoriti obradi podataka u svrhe izravne trgovine, te se osobu čiji se osobni podaci prvi put daju trećim osobama u svrhe izravne trgovine ili se pak njezino ime koristi prvi put u svrhu izravne trgovine treba obavijestiti i dati joj mogućnost besplatnog prigovora na takvo otkrivanje ili obradu.

Države članice moraju osigurati da nadzornik uspostavi odgovarajuće tehničke i organizacijske mjere, kako bi zaštitio osobne podatke od slučajnog ili nezakonitog uništavanja ili slučajnog gubitka, izmjene, neovlaštenog otkrivanja ili pristupa, posebice kad obrada uključuje prijenos podataka preko interneta, kao i osiguranje od drugih nezakonitih oblika zarade. Države članice su obvezne osigurati da nadzornik ili pak njegov zastupnik obavijeste nadzorno tijelo koje je nadležno za zaštitu osobnih podataka ${ }^{9}$ prije izvršavanja potpune ili djelomične automatske obrade podataka ili pak skupa takvih obrada s namjerom da služi jednoj svrsi ili nekoliko povezanih svrha. Direktiva omogućuje državama članicama pojednostavljivanje procedure, kao i iznimku od obavješćivanja u sljedećim taksativno navedenim slučajevima:

- kada za vrste obrade s obzirom na podatke koje je potrebno obraditi nije vjerojatno da će negativno utjecati na prava i slobode osoba čiji se podaci obrađuju;

- kada nadzornik imenuje službenika za zaštitu podataka, koji treba osigurati na neovisan način primjenu nacionalnih odredbi donesenih sukladno odredbama Direktive te vodi evidenciju operacije osobnih podataka.

Glede prijenosa osobnih podataka zemljama izvan Europske unije, države članice će to dopustiti jedino ako je u trećoj zemlji važeća pravna regulativa sukladna s pravnom regulativom države članice. Države članice i Komisija međusobno se obavještavaju koje treće zemlje ne osiguravaju odgovarajuću

medicinske dijagnostike, zdravstvene skrbi ili liječenja ili upravljanja zdravstvenim službama, kada te podatke obrađuje zdravstveni radnik koji na temelju nacionalnog zakonodavstva ili pravila koje donose nadležna tijela podliježe obvezi čuvanja profesionalne tajne. Iznimka je i obrada podataka koji se odnose na kaznena djela, kaznene presude ili pak sigurnosne mjere. Ti se podaci mogu obrađivati jedino pod nadzorom službenog tijela, ili ako je nacionalnim zakonodavstvima predviđena odgovarajuća zaštita, s tim da se evidencija kaznenih presuda mora isključivo voditi pod nadzorom službenog tijela.

9 U Republici Hrvatskoj to je Agencija za zaštitu osobnih podataka, op. autora. 
Dr. sc. Mirko Klarić: Zaštita osobnih podataka i europska konvencija za zaštitu ljudskih prava i... Zbornik radova Pravnog fakulteta u Splitu, god. 53, 4/2016., str. 973.-990.

razinu pravne zaštite. Ako Komisija utvrdi da zemlja izvan Europske unije ne osigurava odgovarajuću zaštitu, države članice poduzimaju mjere potrebne za sprečavanje bilo kakvog prijenosa podataka iste vrste trećoj zemlji. ${ }^{10}$

Sukladno Direktivi, svaka država članica treba osigurati jedno ili više nadzornih javnih tijela na svom području, koja su odgovorna za nazor primjene odredbi koje su donijele države članice u skladu s Direktivom. Ova tijela u provedbi svojih funkcija trebala bi djelovati neovisno. Svako bi tijelo trebalo sadržavati istražne ovlasti koje uključuju ovlast pristupa podacima koji su predmet obrade te ovlast za prikupljanje podataka koji su potrebni za izvršavanje nadzornih dužnosti. Ono bi trebalo imati učinkovite ovlasti za posredovanje, kao što je, primjerice, mogućnost davanja mišljenja prije nego se potupci obrade izvrše, kao i ovlast naređivanja blokiranja, brisanja ili uništavanja podataka, nametanja privremene ili konačne zabrane obrane, upozoravanje ili opominjanje nadzornika ili upućivanje predmeta nacionalnim parlamentima ili drugim političkim institucijama. Posebno su značajne i ovlasti za sudjelovanje u sudskim postupcima ako su prekršene nacionalne odredbe vezane uz zaštitu osobnih podataka, a donesene u skladu s Direktivom. Nadzorno tijelo razmatra zahtjeve koje podnese bilo koja osoba ili bilo koja udruga koja zastupa tu osobu, a vezano uz zaštitu njezinih prava i sloboda koje se odnose na obranu osobnih podataka. Nadzorna tijela također razmatraju zahtjeve koji su vezani za provjeru zakonitosti obrade podataka. Članovi nadzornih tijela i po prestanku radnog odnosa u nadzornim tijelima čuvaju činjenice i podatke do kojih su došli u svom radu kao profesionalnu tajnu. Za provedbu ove Direktive osnovan je Odbor, koji se sastoji od predstavnika država članica, a njime predsjeda predstavnik Komisije. Predstavnik Komisije podnosi Odboru prijedlog mjera koje je potrebno poduzeti, a Odbor dostavlja svoje mišljenje o prijedlogu u roku koji Predsjedatelj može odrediti, vodeći računa o hitnosti predmeta.

Države članice dužne su, temeljem ove Direktive, donijeti nacionalne propise potrebne za usklađivanje s ovom Direktivom.

10 Iznimke od ovog pravila prema kojem se obustavlja prijenos osobnih podataka trećoj zemlji: kada osoba čiji se podaci obrađuju daje svoju nedvosmislenu suglasnost za prijenos podataka, kad je prijenos potreban radi izvršenja ugovora između osobe čiji se podaci obrađuju i nadzornika ili kako bi se provele predugovorne mjere poduzete na zahtjev osobe čiji se podaci obrađuju, kada je prijenos potreban za sklapanje ili izvršavanje ugovora sklopljenog u interesu osobe čiji se podaci obrađuju između nadzornika i treće strane, kada je prijenos potreban ili propisan zakonom radi važnog javnog interesa ili uspostave, izvršavanja ili obrane prava na pravne zahtjeve, kada je prijenos potreban kako bi se zaštitili vitalni interesi osobe čiji se podaci obrađuju, kada se prijenos obavlja iz evidencije koja u skladu sa zakonima ili propisima treba javnosti pružiti podatke i koja je na raspolaganju javnosti općenito ili svakoj osobi koja može dokazati svoj pravni interes u mjeri u kojoj su u određenom slučaju ispunjeni uvjeti u vezi s dostupnosti propisani zakonom. 


\section{ZAŠTITA OSOBNIH PODATAKA U REPUBLICI HRVATSKOJ}

U Republici Hrvatskoj pitanje obrade osobnih podataka usklađeno je s europskom pravnom stečevinom, te je posebno uređeno Zakonom o zaštiti osobnih podataka. ${ }^{11}$ Osim toga, kao takvo, dignuto je i na ustavnu razinu. Tako se u Ustavu Republike Hrvatske, u poglavlju III., pod nazivom Zaštita ljudskih prava i temeljnih sloboda, u potpoglavlju 2., koje nosi naziv „Osobne i političke slobode i prava“, u čl. 39. navodi: Svakome se jamči sigurnost i tajnost osobnih podataka. Bez privole ispitanika, osobni se podaci mogu prikupljati, obradivati i koristiti samo uz uvjete određene zakonom. Zakonom se uređuje zaštita podataka te nadzor nad djelovanjem informatičkih sustava $u$ državi. Zabranjena je uporaba osobnih podataka suprotna utvrđenoj svrsi njihovog prikupljanja“.

U temeljnim odredbama ovog Zakona navodi se kako je zaštita osobnih podataka u Republici Hrvatskoj osigurana svakoj fizičkoj osobi, neovisno o državljanstvu i prebivalištu, te neovisno o rasi, boji kože, spolu, jeziku, vjeri, političkom ili drugom uvjerenju, nacionalnom ili socijalnom porijeklu, imovini, rođenju, naobrazbi, društvenom položaju i drugim osobinama. Osobni podatak je svaka informacija koja se odnosi na identificiranu fizičku osobu koja se može identificirati. Osoba koja se može identificirati jest osoba čiji se identitet može utvrditi izravno ili neizravno, posebno na osnovi identifikacijskog broja ili jednog ili više obilježja specifičnih za njezin fizički, psihološki, mentalni, gospodarski, kulturni i socijalni identitet. ${ }^{12}$ Posebno je važno napomenuti kako Zakon dosljedno slijedi europsku regulativu, pa se u Zakonu izričito određuje kada se osobni podaci mogu prikupljati i dalje obrađivati. ${ }^{13}$ Prema odredbama Zakona, postoje i posebne kategorije osobnih podataka, čija je obrada dodatno ograničena. Navedena su ograničenja postavljena da bi se osigurala dodatna zaštita, koja je nužna zbog posebne osjetljivosti ovih kategorija. Stoga se ovim podacima pruža i dodatna zaštita, kako ne bi došlo do eventualnih zlouporaba prilikom prikupljanja i daljnje uporabe podataka. Radi se o kategorijama podataka koji se odnose na rasno ili etničko porijeklo, politička

11 Narodne novine br. 103/03, 118/06, 41/08, 130/11, 106/12.

12 Zakon također definira pojmove koji su vezani za obradu osobnih podataka, zbirku osobnih podataka, voditelja zbirke osobnih podataka i dr.

13 Pa se tako navodi da se osobni podaci mogu prikupljati uz privolu ispitanika samo za svrhu za koju je ispitanik dao privolu, zatim u slučajevima određenima zakonom, u svrhu izvršavanja zakonskih obveza voditelja zbirke osobnih podataka, u svrhu sklapanja i izvršenja ugovora kojem je ispitanik stranka, u svrhu zaštite života i tjelesnog integriteta ispitanika ili druge osobe, u slučaju kada ispitanik fizički ili pravno nije u mogućnosti dati svoj pristanak, ako je obrada podataka nužna radi ispunjavanja zadataka koji se izvršavaju u javnom interesu, ili kada se izvršavaju javne ovlasti koje imaju voditelj zbirke osobnih podataka i treća strana kojoj se podaci dostavljaju, ako je obrada nužna u svrhu zakonitog interesa voditelja zbirke osobnih podataka ili treće strane kojoj se podaci otkrivaju, te ako je osobne podatke ispitanik sam objavio. 
stajališta, vjerska ili druga uvjerenja, sindikalno članstvo, zdravlje i spolni život, te vođenje kaznenih i prekršajnih postupaka. Ograničenje je postavljeno kao generalna klauzula po kojoj je načelno zabranjeno takve kategorije podataka prikupljati, ali se taksativno navode iznimke pod kojima se ti podaci mogu prikupljati i obrađivati. Važnu ulogu u zaštiti osobnih podataka ima Agencija za zaštitu osobnih podataka, kao regulatorno tijelo ovlašteno za provedbu Zakona i nadzor nad prikupljanjem i obradom osobnih podataka. U obavljanju svojih poslova Agencija je samostalna i odgovara Hrvatskom saboru. Glavne ovlasti Agencije su: nadzor provođenja zaštite osobnih podataka, ukazivanje na uočene zlouporabe kod prikupljanja osobnih podataka, sastavljanje lista država i međunarodnih organizacija koje imaju odgovarajuće uređenu zaštitu osobnih podataka, rješavanje povodom zahtjeva za utvrđivanje povrede prava zajamčenih Zakonom te vođenje središnjeg registra. ${ }^{14}$

\section{ZAŠTITA OSOBNIH PODATAKA U NEKIM ZEMLJAMA EUROPSKE UNIJE}

I druge zemlje članice Europske unije također imaju propise, usklađene s Direktivom, kojima su uređuje zaštita osobnih podataka.

Velika Britanija donijela je Zakon o zaštiti podataka 1998. godine ${ }^{15}$ Zakon se sastoji od 6 dijelova, gdje se vrlo sustavno i cjelovito opisuju prava osoba čiji se podaci prikupljaju i obrađuju, ovlasti i odgovornosti regulatornog tijela, iznimke od primjene propisa kao i sankcije u slučaju povrede odredbi Zakona. Osobni podaci, prema odredbama ovog Zakona, predstavljaju one podatke koji se odnose na fizičke osobe koje mogu biti identificirane ili određene tim podacima, ili pak mogu biti odredive temeljem tih podataka i drugih informacija kojima raspolaže primatelj informacije. U Zakonu o zaštiti podataka sadržano je osam načela, koja određuju kako se osobni podaci trebaju koristiti. Ova su načela utemeljena na premisama koje bi trebao sadržavati svaki dobar sustav gospodarenja osobnim podacima. Ova se načela primjenjuju kako na podatke dostupne on-line, tako i na podatke dostupne off-line. Prema prvom načelu, osobni podaci trebaju biti korektno i zakonito obrađeni. Nadalje, osobni podaci mogu biti korišteni samo za jednu ili više specificiranih i zakonitih svrha, te se ne smiju dalje koristiti ni u kojoj mjeri u

14 Agencija nadzire provođenje zaštite osobnih podataka na zahtjev ispitanika, na prijedlog treće strane ili po službenoj dužnosti. Pored toga, Agencija prati uređenje zaštite osobnih podataka u drugim zemljama, nadzire iznošenje osobnih podataka iz Republike Hrvatske, izrađuje metodološke preporuke za unapređenje zaštite osobnih prava i dostavlja ih voditeljima zbirki osobnih podataka, daje savjete u svezi $\mathrm{s}$ uspostavom novih zbirki osobnih podataka, daje mišljenja, daje preporuke i prijedloge za unapređenje i zaštitu osobnih podataka, surađuje s nadležnim državnim tijelima u izradi prijedloga propisa koji se odnose na zaštitu osobnih podataka.

15 Data Protection Act, http://www.legislation.gov.uk/ukpga/1998/29/contents. 
svrhe koje su inkopatibilne svrhama zbog kojih su podaci prikupljani i obrađeni. Podaci trebaju biti adekvatni, relevantni i ne smiju biti prekomjerni u odnosu na svrhu za koju se prikupljaju. Osobni podaci trebaju biti točni te, ukoliko je to potrebno, voditi računa o njihovoj ažurnosti. Osobni podaci koji se prikupljaju za određenu svrhu ne bi se trebali čuvati dulje nego je potrebno za realizaciju te svrhe. Osobni podaci trebali bi biti obrađeni u skladu s pravima ispitanika čiji se podaci obrađuju. Odgovarajuće tehničke i organizacijske mjere trebale bi biti poduzete na način da se obrada osobnih podataka odvija bez njihova slučajnog gubitka, oštećenja ili uništenja. Osobni podaci mogu biti dostavljeni u treće zemlje izvan europskog gospodarskog prostora jedino ukoliko ta zemlja osigurava odgovarajuću razinu zaštite tih podataka, te prava osoba čiji se podaci obrađuju.

U Njemačkoj je donesen Savezni zakon o zaštiti podataka, koji sadrži posebne odredbe za obradu osobnih podataka u javnom i privatnom sektoru. Njemačka ima posebne propise za elektoničke informacijske i komunikacijske servise, kao i posebne propise koji se odnose na operatere elektroničkih signala. ${ }^{16}$ Njemački su propisi koji se odnose na zaštitu osobnih podataka usklađeni s Direktivom 46/95/EC. U Njemačkoj je generalno zabranjeno prikupljanje i korištenje osobnih podataka, osim ako ne postoji izričito zakonsko dopuštenje, odnosno ukoliko osoba čiji se podaci prikupljaju ne dade suglasnost. Njemački zakon slijedi odredbe Direktive vezane uz prava i zaštitu osoba čiji se podaci prikupljaju, sigurnosne uvjete koji se trebaju ispuniti prilikom prikupljanja i obrade podataka, obvezu prikupljanja samo onih podataka nužnih za ispunjenje svrhe zbog koje se podaci prikupljaju i obrađuju, postavljanje ograničenja vezanih uz lokaciju prikupljanja i obrade podataka te mogućnost dostave podataka u treće zemlje izvan Europske unije. ${ }^{17} \mathrm{U}$ Njemačkoj zaštita osobnih podataka ima ustavnu snagu, pa se time jamči dostojanstvo ljudske osobe i poštovanje njezinih ljudskih prava. Zbog toga je Savezni ustavni sud postavio ograničenje prema kojem je obrada osobnih podataka moguća samo u slučaju da postoji zakonska osnova ili izričito dopuštenje osobe čiji se podaci obrađuju. U Njemačkoj djeluje Savezni povjerenik za podatke te 16 zemaljskih tijela za zaštitu osobnih podataka. Uloga saveznog povjerenika jest nadzor obrade podataka od strane federalne vlade, gdje državna tijela obrađuju podatke koji su u posjedu tijela javne vlasti. Zemaljska tijela vrše nadzor nad obradom osobnih podataka od strane privatnih tijela. Državna tijela pomažu javnosti u nadzoru nad

16 Usp. Jotzo, F.: Gilt deutsches Datenschutzrecht auf für Google, Facebook \& Co bei Grenzüberschreitendem Datenverkher?, MultiMedia und Recht, 2009., str. 232-237.

17 Gola, P. - Shomerus, R.: BDSG Bundesdatenschutzgesetz. Kommentar, 10. Auflage, Beck, Munchen, 2009. 
radom organizacije koja obrađuje osobne podatke. Osim toga, ova tijela snažno utječu na zaštitu osobnih podataka, kao i anonimnosti osoba na internetu. ${ }^{18}$

Zaštita osobnih podataka u Francuskoj započinje sedamdesetih godina prošlog stoljeća donošenjem Zakona o informacijskim tehnologijama, bazama podataka i građanskim slobodama. ${ }^{19}$ U Ustavu Francuske nema odredbi koje bi uređivale zaštitu osobnih podataka. Tek je donošenjem i primjenom Zakona o informacijskim tehnologijama, bazama podataka i građanskim slobodama uvedena zaštita osobnih podataka u Francuskoj. Navedeni je zakon nekoliko puta dopunjavan, kako bi bi se uskladio s direktivama Europske unije vezanim uz zaštitu osobnih podataka. Ipak, valja napomenuti kako Francuska predstavlja jednu od prvih država koje su regulirale zaštitu osobnih podataka. U skladu s pravom na pristanak, osobe koje imaju pravni interes vezan uz pristup informacijama uživaju sljedeća prava: pravo na informaciju, pravo na pristup, pravo na ispravak ili poništavanje infirmacije kao i pravo na anuliranje informacije. Zakon izravno ne spominje zaštitu prava maloljetnika, ali se velika pozornost ulaže informiranju roditelja i djece o odgovornijem korištenju interneta, što se pokušava ostvariti kroz snažne medijske kampanje kao i edukaciju u školama. U Zakonu se također predviđa osnivanje Povjerenstva za zaštitu osobnih podataka, čije su ovlasti naknadno proširene. ${ }^{20}$ Primarna uloga Povjerenstva informiranje je subjekata koji se koriste podacima, te nadzor nad ostvarivanjem i poštovanjem njihovih prava i obveza. ${ }^{21}$

U Nizozemskoj je trenutno naglasak na zaštiti osobnih podataka osoba koje koriste suvremenu informacijsku i komunikacijsku tehnologiju. Kao rezultat razvoja suvremenih informacijskih tehnologija, snažno je raširena uporaba interneta, društvenih mreža i pametnih telefona. U samom su pak nizozemskom Ustavu ugrađene odredbe o zaštiti osobnih podataka. Trenutno je u Nizozemskoj na snazi Zakon o zaštiti osobnih podataka, koji uređuje zaštitu osobnih podataka. ${ }^{22}$ Što se pak tiče zaštite privatnosti na internetu, ona je regulirana Zakonom o telekomunikacijama, u koji su ugrađene odredbe vezane uz zaštitu osobnih podataka u elektroničkoj komunikaciji. Nizozemska je također ugradila ključne direktive Europske unije o privatnosti koje uređuju pitanja zaštite i čuvanja osobnih podataka

18 Ott, J.: Shutz der Nutzerdaten bei Suchmaschinen - Ich weiß, wonach du letzten Sommer gesucht hast ..., Multimedia und Recht, 2009., str. 448-453.

19 Usp. http://legifrance.gouv.fr/affichTexte.do?cidTexte=JORFTEXT000000886460\&fastPos $=1 \& \mathrm{f}$ astReqId=411489546\&categorieLien=cid\&oldAction=rechTexte. Preuzeto 10. lipnja 2015.

20 Usp. http://www.cnil.fr/english/the-cnil/. Preuzeto 10. lipnja 2015.

21 Usp. http://www.loc.gov/law/help/online-privacy-law/france.php. Preuzeto 12. lipnja 2015. Usp. Gonzales Fuster, G.: The Emergence of Personal Data Protection as a Fundamental Right of the EU, Springer International Publishing, 2014., str. 61-65.

${ }_{22}$ Usp. http://www.coe.int/t/dghl/standardsetting/dataprotection/national\%20laws/NL_DP_LAW. pdf. Preuzeto 12. lipnja 2015. 
te korištenje podataka i privatnost korisnika u elektroničkim komunikacijama. ${ }^{23}$ I u Nizozemskoj je obrada podataka strogo ograničena te se traži izričita suglasnost subjekta čiji se podaci obrađuju. Osim toga, pojedine kategorije podataka, poput pitanja o religiji, ne mogu biti predmet prikupljanja i obrade podataka. ${ }^{24}$ Pružatelji internetskih usluga također imaju obvezu zaštititi privatnost korisnika i pretplatnika različitih elektroničkih servisa. Glavna agencija koja osigurava zaštitu osobnih podataka jest Nizozemska ustanova za zaštitu osobnih podataka, koja je započela s radom 2001. godine. ${ }^{25}$ Što se pak tiče zaštite privatnosti korisnika informacijskih i komunikacijskih servisa, glavnu ulogu ima Neovisno poštansko i telekomunikacijsko tijelo Nizozemske, osnovano 1997. godine. Kako se radi o neovisnom regularnom tijelu, nizozemska Vlada ne može izravno utjecati na njezin rad. Međutim, ministar ima neizravan utjecaj jer bira članove regulatornog tijela i odobrava njegov proračun.

\section{ISTRAŽIVANJE EUROBAROMETRA VEZANO UZ ZAŠTITU PODATAKA I ELEKTRONIČKOG IDENTITETA U EUROPSKOJ UNIJI}

Eurobarometar je proveo istraživanje na području Europske unije u studenome i prosincu 2010. godine, kojem je za cilj bilo utvrditi predodžbe koje su vezane uz zaštitu osobnih podataka, kao i uz zaštitu elektroničkih identiteta u Europskoj uniji. ${ }^{26}$

Istraživanje je pokazalo da $74 \%$ ispitanika u Europskoj uniji drži kako je otkrivanje osobnih podataka nešto što predstavlja sastavni dio suvremenog načina života, a u osobne se informacije uglavnom ubrajaju financijske, medicinske kao i one koje se odnose na nacionalni identitet. ${ }^{27} \mathrm{Na}$ društvenim mrežama korisnici u $79 \%$ slučajeva otkrivaju svoje ime, u $51 \%$ stavljaju fotografiju, a u $47 \%$ otkrivaju nacionalnost. On-line kupci koji daju svoje osobne podatke uglavnom otkrivaju svoja osobna imena (90\%), kućne adrese (89 \%) i brojeve mobilnih telefona (46 $\%$ ). Najvažniji su razlog za pristupanje društvenim mrežama i otkrivanje osobnih

23 Usp. http://www.loc.gov/law/help/online-privacy-law/netherlands.php. Preuzeto 12. lipnja 2015.

24 Usp. Lozina, D. - Klarić, M.: Nova javna uprava, Pravni fakultet Sveučilišta u Splitu, Split, 2003., str. 86 .

25 Usp. https://clientsites.linklaters.com/Clients/dataprotected/Pages/TheNetherlands.aspx. Preuzeto 12. lipnja 2016.

26 Special Eurobarometar 359; Atitudes on Data Protection and Electronic Identity in the European Union, Fieldwork: November - December 2010., Publication June 2011.

${ }^{27}$ Oko $75 \%$ ispitanika smatra da su financijske informacije osobne, $74 \%$ ispitanika drži da su medicinske informacije osobne, a $73 \%$ ispitanika misli isto o informacijama koje se odnose na nacionalni identitet. 
podataka druženje i komunikacija s drugim korisnicima te kupnja preko interneta. Nadalje, $43 \%$ korisnika interneta smatra da je bilo traženo više osobnih informacija nego što je to potrebno za pristup uslugama ili korištenje on-line serivisa. Većina građana Unije zabrinuta je mogućnošću čuvanja svojih korisničkih navika vezanih uz on-line kupnju putem kreditnih kartica (54\%), mobilnih telefona (49\%) te mobilnim internetom (40\%). Gotovo 6 od 10 korisnika interneta čita izjave o privatnosti, a većina od onih koji ih čitaju prilagođava svoje ponašanje sukladno tim izjavama. Oko polovice internetskih korisnika informirano je o uvjetima skupljanja podataka i daljnjem korištenju podataka kada se pridruže društvenim mrežama ili se registriraju za korištenje on-line usluga. Samo je jedna trećina građana Europske unije upoznata s postojanjem nacionalnih javnih tijela odgovornih za zaštitu njihovih prava koja se odnose na osobne podatke. Europski građani koriste različite vrste identifikacijskih isprava kod internetske kupovine. Većina koristi kreditne i bankovne kartice izdane od strane banaka (74 \%), zatim osobne iskaznice i potvrde o prebivalištu (68\%), kartice izdane od strane javnih tijela (65\%) te vozačke dozvole (63\%). Oko $35 \%$ građana ima korisničke račune koje koriste na internetu kao što su računi e-mail adresa, za logiranje na društvene mreže ili pak za korištenje komercijalnih servisa. Kako bi zaštitili svoj identitet u svakodnevnom životu, većina građana Unije (62 \%) daje minimalnu količinu podataka koja se zahtijeva prilikom registracije. Kako bi zaštitili svoj identitet na internetu, najčešće strategije su tehničke ili proceduralne, primjerice sredstva i strategije za ograničavanje neželjene elektroničke pošte poput spama, koje koristi $42 \%$ ispitanika, provjera zaštićenosti transakcija, koje koristi $40 \%$ ispitanika, te korištenje protušpijunskih softvera, koje koristi ukupno 39 $\%$ ispitanika. Tijelima i institucijama, uključujući Europsku komisiju i Europski parlament, vjeruje $55 \%$ ispitanika više nego komercijalnim tvrtkama. Manje od trećine telekomunikacijskih kompanija i pružatelja internetskih usluga, kao i petina internetskih tvrtki uživa povjerenje ispitanika. Čak je $70 \%$ građana Unije zabrinuto da će se osobni podaci kojima raspolažu privatne tvrtke koristiti u svrhe za koje nisu bili prikupljani. Sukladno pravu na zaborav, velika većina ispitanika (75\%) želi izbrisati osobne podatke na web-stranici, kad god to požele. Iako se većina korisnika interneta u Europskoj uniji smatra odgovornima za sigurno korištenje vlastitih osobnih podataka, 90 \% njih želi bolju ili jadnako kvalitetnu zaštitu od strane tijela Unije. Čak $44 \%$ ispitanika preferira zaštitu osobnih podataka na razini Europske unije, dok $40 \%$ ispitanika smatra da je primjerenija zaštita na razini država članica. Većina ispitanika vjeruje kako će njihovi podaci biti bolje zaštićeni u većim tvrtkama, ukoliko se te tvrtke obvežu da će na poslovima zaštite osobnih podataka angažirati službenika za zaštitu osobnih podataka. Ispitanici su podijeljeni oko mogućnosti da policija ima uvid u osobne podatke. S druge strane, gotovo da 
postoji suglasje oko toga da treba posebno zaštititi osobne podatke maloljetnika (95 $\%)$, kao i da je potrebna posebna zaštita genetskih podataka $(88 \%) .{ }^{28}$

\section{ZAKLJUČAK}

Predmet ovoga rada bila je zaštita osobnih podataka kao posebne kategorije ljudskih prava u svjetlu Europske konvencije za zaštitu ljudskih prava i temeljnih sloboda. Analizirajući odnos između Europske konvencije za zaštitu ljudskih prava i temeljnih sloboda, te propise koji uređuju prikupljanje i obradu osobnih podataka, može se reći kako zaštita osobnih podataka nesumnjivo spada u kategoriju temeljnih ljudskih prava koja se, zbog razvoja suvremenih komunikacijskih i informacijskih tehnologija, nailazi pred snažnim izazovima. Odredbe same Konvencije ne razrađuju detaljno pitanje zaštite privatnosti pojedinca, nego se koriste opći termini kao „poštovanje privatnog i obiteljskog života“, „poštovanje (nepovredivosti) doma“ i „poštovanje prava na dopisivanje“. Očito je da je taj dio Konvencije „lex generalis“ u odnosu na druge pravne akte koji uređuju zaštitu osobnih podataka, ali je, na temelju ovako postavljenih općih definicija vezanih uz zaštitu privatnosti pojedinca, Konvencija pokušala u najširem smislu obuhvatiti generalno pravo na privatnost pojedinca kao jedno od temeljnih ljudskih prava. Razlog zbog kojeg jedna kategorija ljudskih prava, kao što je pravo na zaštitu osobnih podataka, vezano uz njihovo prikupljanje i obradu, vjerojatno leži u tome što je napredak tehnologija i automatizacija u obradi podataka toliko napredovala, da praktično danas nema osobe koja se u bilo kojem trenutku ne može naći izložena ugrozi od kršenja svojih prava na privatnost. Moglo bi se stoga zaključiti kako Europska konvencija za zaštitu ljudskih prava i temeljnih sloboda predstavlja univerzalan pravni instrument za zaštitu ljudskih prava općenito, dok pojedine kategorije ljudskih prava, kao što su osobni podaci, mogu imati i dodatnu pravnu zaštitu, ovisno o okolnostima i potrebama u društvu.

Zaštita osobnih podataka ima posebnu važnost i za samu javnu upravu, jer ona po prirodi svoje funkcije, raspolaže velikim brojem osobnih podataka građana, koji se odnose na njihov društveni, ekonomski i socijalni položaj u zajednici. Upravo su zbog toga važna istraživanja, poput onog koje je proveo Eurobarometar o percepciji građana vezanoj uz zaštitu osobnih podataka. Time se mogu izvesti i određeni zaključci o senzibiliziranosti građana za pojedine elemente zaštite osobnih podataka. Temeljem toga, trebalo bi razmišljati o razvijanju sigurnosnih

28 Ovdje su samo izneseni osnovni podaci, koji odražavaju stajališta građana Europske unije o osobnim podacima građana i njihovoj zaštiti na internetu. Samo istraživanje je puno temeljitije te daje detaljnu analizu stajališta građana, gdje se mogu praviti određene usporedbe kako po zemljama tako i po pojedinim pitanjima koja su vezana uz korištenje osobnih podataka. 
mehanizama i procedura koje bi osigurale bolju i kvalitetniju zaštitu podataka kojima raspolažu tijela javne vlasti, te bi se i na taj način osiguralo kvalitetniji rad upravnih tijela. Pored ovih posebnih propisa koji osiguravaju zaštitu prava građana, očito je i to da opći propisi o temeljnim ljudskim pravima i slobodama, poput Europske konvencije za zaštitu ljudskih prava i sloboda, sa svojim pravnim mehanizmima mogu predstavljati dodatni izvor zaštite osobnih podataka. Pitanje zaštite prikupljanja i obrade osobnih podataka pitanje je koje nadilazi nacionalnu razinu i u svjetlu razvoja suvremenih komunikacijskih i informacijskih tehnologija postaje jedno od fundamentalnih pitanja vezanih uz zaštitu ljudskih prava na generalnoj razini.

\section{PROTECTION OF PERSONAL DATA AND “ECHR"}

Focus of this article is in protection of personal data as a elementary human right in scope of Convention for the Protection of Human Rights and Fundamental Freedoms. In article is also analysed regulations in Convention for the Protection individuals with regard to Automatic Processing of Personal Data Council of Europe, as a main legal act which regulate protection of personal data and right on individual on privacy. This Convention can be treated as lex specialis because create regulatory framework for one category of human rights: rights on privacy and protection of personal data. That category became more and more important because of highly technological development. In article is also presented regulatory framework related on personal data protection in five European countries: Croatia, Great Britain, France, Germany and Nederland. At the end of the article are presented empirical indicators which correlate with using of personal data. In concluding remarks has been described important role of personal data protection as a special type of protection of human rights in light of Convention for the Protection of Human Rights and Fundamental Freedoms.

Key words: public administration, human rights and basic freedoms, personal data protection 